\title{
Representament and Object (RO) Marking Iconicity Relationship in Wardah Cosmetics Commercial TV Advertising
}

\author{
Somadi \\ Faculty of Cultural Sciences, Hasanuddin University, Makassar, Indonesia \\ Tadjuddin Maknun \\ Faculty of Cultural Sciences, Hasanuddin University, Makassar, Indonesia \\ Ikhwan M. Said \\ Faculty of Cultural Sciences, Hasanuddin University, Makassar, Indonesia \\ Munira Hasjim \\ Faculty of Cultural Sciences, Hasanuddin University, Makassar, Indonesia
}

\begin{abstract}
This study aims to examine the relationship between representament and object iconicity in Wardah's cosmetic commercial television commercials, which include shampoo, BB cream, mascara, lipstick, and social activities. Wardah cosmetic commercial television commercials attempt to construct consumers using the concept of "Beauty from the heart". Meanwhile, the beauty of cosmetic users is always visible physically. Thus, it cannot be proven to be real beauty from the heart when someone uses cosmetics. This study uses a qualitative descriptive method to analyze data in the form of verbal and nonverbal text. The researcher uses Charles Sander Peirce's semiotic theory which divides the signs according to the relationship between the representament (sign) and its object (marker) into icons, indexes, and symbols. The results of this study indicate that beauty can be classified into two categories, namely physical beauty and psychological beauty. Physical beauty relates to the body and the head. There are four parts of the head which are icons of beauty for a young woman: 1) the hair, 2) the facial skin, 3) the eyes, and 4) the lips. Meanwhile, psychological beauty is a beauty from the heart that is manifested in the form of attitudes during social activities. In addition, young women as users of Wardah cosmetics are represented by the use of youthful vocabulary and language typical of the millennial generation.
\end{abstract}

Index Terms - semiotics, representament, object, beauty, cosmetics advertising

\section{INTRODUCTION}

Advertising is a means of communication between producers and consumers; it is a promotional medium for a product, service or other service delivered through certain media. Advertising aims to persuade the audience (the public) to want and to use the products it offers. Therefore, the choice of words and language styles used by advertisers can have multiple interpretations. Works read through the internet media are categorized as cyber literature (Rahman, 2017).

Advertisements (ads) try to seduce consumers through the images that are displayed. Advertisers construct their messages based on a wealth of cultural signification present in their society by using verbal and nonverbal texts (Rahmaniah, 2012). In addition to words and language, advertisements also use symbols and signs displayed by the advertiser. The words and language used are called verbal texts. Meanwhile, the signs that do not use language are called nonverbal texts.

The signs visualized in advertisements can be analyzed to elicit their meaning. From this perspective the researcher needs to interpret the meanings and symbols in the visual content of advertisements. This approach can be applied to the advertisements of the cosmetics company Wardah, enabling these advertisements to be interpreted by identifying the signs contained in the text (both verbal and nonverbal) in order to elucidate the meanings of these signs.

Wardah's advertisements are mainly aimed at influencing consumers through social media and try to construct consumer's self-perception using Wardah's concept: inner beauty. That concept leads to the main issue addressed in this study, which is to examine the ways in which the advertisements connect the concept of beauty from within to external beauty in the form of physical appearance, specifically in the sense that cosmetic users are portrayed as looking physically beautiful (Abidin, 2018). The physical body parts placed on display that are considered to be beautified by the use of these cosmetics are the hair, facial skin, eyes, and lips. Meanwhile, the concept of being beautiful from within cannot be proven physically but psychologically. Inner beauty is character. Furthermore, the character is constructed through behavior, both verbally and nonverbally. 
Pierce introduced the popular semiological model, which is based on the concept of meaningful triangles or relationships between the Interpretant, the Representament and the Object (Hoopes, 2014). Based on this concept, a semiotic study perspective can be adopted to analyze the signs visualized in advertisements in order to understand their meaning. The researcher decided to adopt a semiotic approach to interpret the R-O relationship marking through visualization in Wardah's advertisements. Wardah's advertisements are interpreted by identifying the signs contained in the text (both verbal and non-verbal), so that the meaning of the icon will be seen through these signs.

This research is needed because there are differences in the concept of Wardah cosmetic advertisements in terms of the advertisement content and what is being advertised. The concept of being beautiful from the inside is different from the beauty from the outside, with the latter directly influenced by the use of cosmetic tools. Beauty from the inside relates to attitudes and behavior, while beauty that results from using cosmetics is purely physical beauty (Abidin, 2018). To address this issue, the study aims to examine the relationship between the marking of Representament (R) and Object (O) beauty iconicity. The beauty icon in Wardah cosmetics is closely related to the body on the head. In other words, there is a relationship of beauty iconicity on the part of the head, namely the hair, facial skin / face, eyes and lips.

In connection with this study, there are a number of previous studies addressing similar issues. Semiotic research by Osianita (2015) on Mustika Ratu Cosmetics Color Trends product advertising concludes that the meaning of Mustika Ratu's advertisements as a whole is to give a message to readers that applying the Color Trend products to women's faces will make women look beautiful and enchanting. The study by Djamereng (2018) on television advertising by Wardah and Total Almeera concluded that there is an obligation for Muslims to consume halal and good food and drinks (Machmud, et al., 2021). Meanwhile, Situmeang (2015) studied the representation of women in Wardah Cosmetics television commercials, providing a semiotic analysis of Roland Barthes Wardah campaign "Inspiring Beauty Version True Colors" which complements the two afore-mentioned studies, and concludes that the Wardah advertising denotation of True Colors illustrates that women who use Wardah cosmetics can inspire others.

From the above review, it appears that none of the previous studies have fully discussed Wardah cosmetics advertising in terms of semiotic linguistics. In order to remedy this lack, the authors conducted research to investigate the relationship between the marking of Representament $(\mathrm{R})$ and Object $(\mathrm{O})$ signs of beauty icons in Wardah Cosmetics commercial TV advertising, with a particular focus on the iconic beauty of the eyes and the lips..

\section{METHODOLOGY}

This study aimed to examine the relationship between representaments and iconic objects in Wardah's cosmetic commercial television advertisements for products including shampoo, BB cream, mascara, and lipstick, and their relation with social activities. There are four parts of the head which are icons of beauty for a young woman, namely 1 ) the hair, 2) the face/facial skin, 3) the eyes, and 4) the lips. Meanwhile, psychic beauty is the inner beauty that is manifested in the form of a woman's attitude during her daily social activities.

Data were collected from primary and secondary sources. Primary sources include data obtained by downloading information on YouTube channels and / or commercial television related to Wardah cosmetic products, especially shampoo, powder, mascara, and lipstick. Secondary sources (supporting) data were collected through observation, questionnaires by using Google forms, as well as other documentation such as brochure, leaflet and online promotion.

Once the data had been collected, the researcher used several observation techniques. The listening technique involved watching TV commercials of about 30-40 seconds. After downloading TV commercials on the videos, researchers make observations for retrieval of both verbal and nonverbal text data by means of screen captures. The data were then sorted and grouped according to this classification. Once the data were classified, the final step was to analyze the data based on semiotics theory.

\section{LITERATURE REVIEW}

The semiotic theory can be used to analyze advertising materials because it is considered appropriate for studying the various verbal and nonverbal signs contained in advertisements. Charles Sanders Peirce's semiotic theory emphasizes the logic and philosophy of the signs present in a given society. According to Peirce, logic must learn how people reason. Fundamental reasoning is done through signs relating to other people, and giving meaning to what the universe displays.

Furthermore, Peirce identified the elementary particles of the sign and recombined all the components in a single structure. A sign or representament is something that represents something else in some way or capacity. That something else is called the interpretant, and refers to a particular object. Thus, a direct sign has its interpretant and object (Wibowo, 2013) and is a combination of entity processes (in the form of representations) with other entities called objects.

Peirce calls it the triangle meaning theory. (1) A sign is something that has a physical form that can be grasped by the five human senses and is something that refers (represents) other things outside the sign itself. This reference sign is called an object; (2) The reference to the sign (object) is the social context that becomes the reference of the sign or something that the sign refers to; (3) The user of a sign (interpretant) is the concept of thinking of people who use a sign 
and lower it to a certain meaning or meaning that is in someone's mind about the object referred to by a sign (Peirce, in Situmeang, 2015).

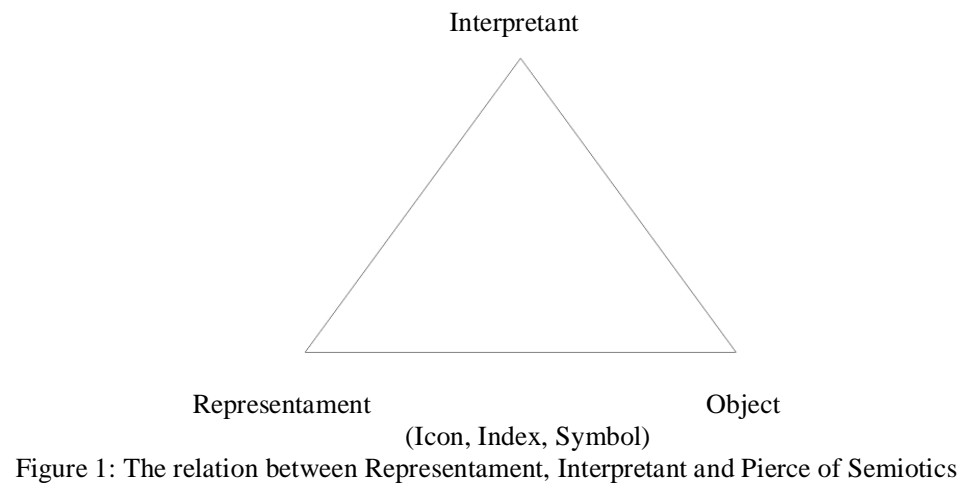

Icons are sign whose markers and markers indicate that they exist or are natural, that is, the markers are the same as the markers. The relationship is a relationship of equality, for example a picture of a person, a portrait or a painting. This study uses Charles Sanders Pierce's semiotic approach as a theoretical basis. Pierce's theory of semiotics is pragmatic, namely semiotics which studies the relationship between signs and their interpreters or users (Budiman, 2011, p.4).

Icons are sign whose relationship between the signifier and the signifier is simultaneous in its natural form. In other words, an icon is a relationship between a sign and an object or a reference that is similar (Sobur, 2004, p.41). Basically, an icon is a sign that can describe the main characteristic of something. An icon is a physical object (two or three dimensions) that resembles what it represents. Pierce's interpretant object sign model is an icon in his attempt to reproduce in concrete the abstract relation structure between its elements.

The marking relationship is a sign (representament is something that replaces something for someone in some way or in its capacity. It agrees to someone, meaning that in that person's mind another equivalent sign / a sign that is more developed is created (Budiman, 2011, p.73; Rahman \& Weda, 2019).

The verbal and nonverbal texts presented in the ad tagline are very constructive when compared to the types of products and can be used as a reflection of what is happening in society, such as the use of Wardah's cosmetics. This social phenomenon is often captured as social codes to serve as the background for the reality of relationships in advertising representations. Each advertisement has its own way of representing and forming an icon to be conveyed to consumers. It is hoped that this will lead to suggestions for consuming the advertised products.

The benefits that can be obtained from this research include 1) theoretical benefits and 2) practical benefits.

\section{DisCUSSION}

\section{A. Analysis of the Relationship between the Representament and Object Iconicity}

The analysis of the relationship between the representament and its object of iconicity in Wardah's Cosmetics TV advertisement has a correlation with body organs on the head. The relationship between RO icons, indexes, and symbols in social activities show that there are several RO relationships between icons, indexes and symbols:

(1) The icons in Wardah's cosmetic advertisements are: 1) the beauty icon in the hair section; 2) the beauty icon for the face; 3) the beauty icon for the eyes; and 4) the beauty icon for the lips.

(2) Index in Wardah's cosmetic advertisements includes: 1) the hair care behavior index; 2) the facial skin care index; 3) the eyelash care index; 4) the lifestyle index of upper and lower strata of society; and 5) a health index (symptoms of acne, lip care).

(3) In the Wardah's cosmetic advertisements, there are several symbol types: 1) beauty symbols, 2) religious symbols, 3) corporate symbols, and 4) social symbols.

Iconicity is an important phenomenon in semiotics. For Pierce, the icon is a sign based on similarity (resemblance) between the representament and the object, whether the object actually exists or not. However, in fact icons do not merely include realistic images such as paintings or photographs, but also expressions such as graphics, schemes, geographic maps, mathematical equations, even metaphors (Budiman, 2011. p. 56). Pierce characterizes the icon as "a sign that (stands for) something simply because it resembles it", as a sign "partaking in the characters of the object"; or as a sign whose "quality reflects the object, evokes analogous sensations in the mind because of the likeness" (Budiman, 2011, p.62). Various iconic signs are scattered around us in everyday life. In Wardah's cosmetic advertisements, hair, facial skin, eyes and lips are the icons of a woman's beauty. What an iconic, but sometimes unthinkable, sign of our life.

Icons are signs that are based on the similarity between the sign (representament) and the object, although they do not rely solely on "naturalistic" imagery as it is, because graphical schemes or maps are also considered icons (Budiman, 2011, p.23). The type of sign that is based on the resemblance is an iconic sign, and the symptoms can be called 
iconicity (Sari, 2014). Icons are not only signs found in visual communication (Weda, et al., 2021), but also in almost all semiotic fields, including in language (Budiman, 2011, p. 62).

Pierce classified the types of icons in a tripartite manner, namely image icons, diagram icons, and metaphorical icons. The metaphor icon (metaphor) is a meta-sign (metasign) whose iconicity is based on the similarity or similarity between the objects of two symbolic signs (Budiman, 2011, p.66; Hasyim, 2015). Metaphors are icons based on the similarity between objects of two symbolic signs (Budiman, 2011, p.74). It is usually in the form of a similarity relationship abstract relation such as similarity of properties. Icons are not always based on similarities as in everyday "lay" understanding, but also similarity in terms of abstract relations or structural homology (Budiman, 2011, p. 62). Abstract relations can be similarities of properties. This paper will discuss icons in metaphor, based on the examples shown in Fig. 1 which cover the icon, index and symbol classes listed above.

a.

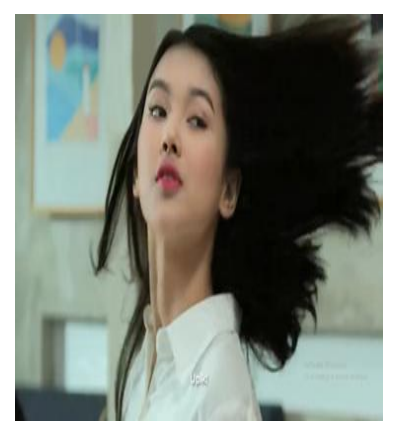

F2

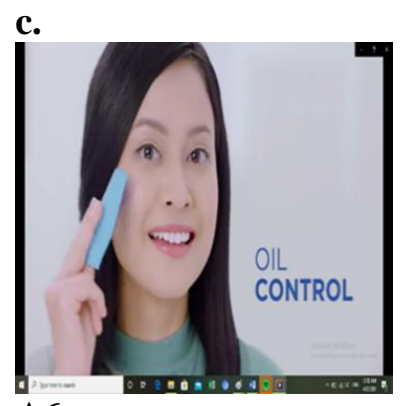

A6

e.

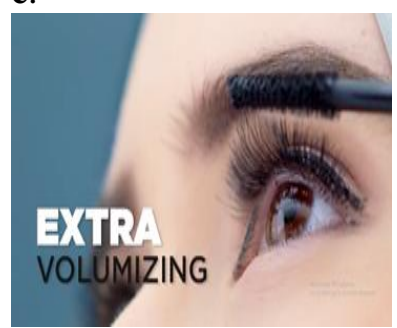

$\mathrm{H}$

g.

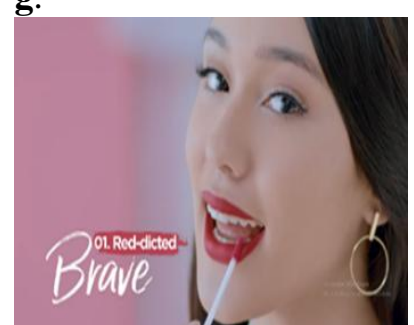

E4
Verbal text in the form of an expression:

Upi, "Udah stop, ga usah pakai slowmoslowmo lagi!

Text:

"OIL CONTROL"

Followed by the Oral language:

"dengan hasil yang matte + oil control, Hight by kilap"

Text:

"EXTRA

VOLUMIZING"

Narration followed:

Ekstra tebal, Ekstra lebih"

Text:

$01 \quad$ Red-dicted

Brave

Followed by the verbal narrative:

"Merah, untuk percaya diri"

Figure 2: Verbal Texts of the Ads b.

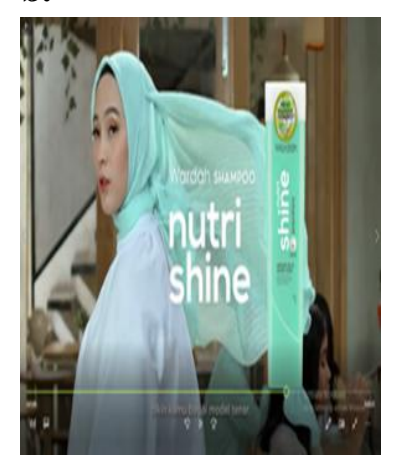

F4

d.

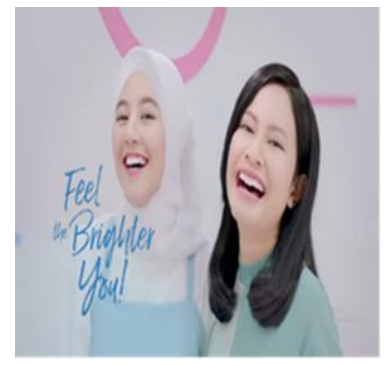

A9

f.

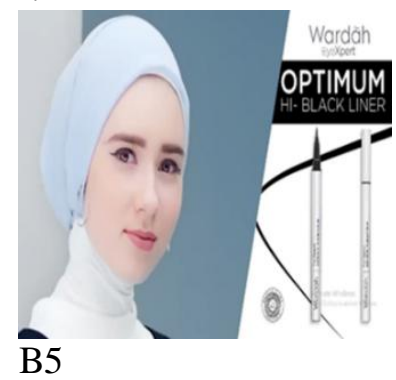

h.

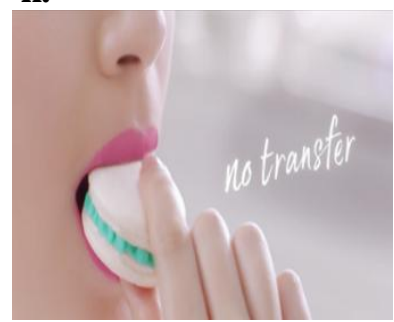

P3

Verbal text in the form of writing: Wardah Nutrishine Shampoo. Followed by the speech text which reads: "Bu Hesty..." "Rambut tampak sehat bersinar. Bikin kamu bagai model tenar. Pakai selalu Wardah Nutrishine Shampoo yang halal berbahan natural; Mengandung argan oil untuk nutrisi rambut agar tampak sehat dan berkilau".

Text:

"OIL CONTROL"

Followed by the Oral language:

"dengan hasil yang matte + oil control, Hight by kilap"

Text:

"Wardah Eyexpert Optimum

Hi-Black Liner"

Spoken Language: "Wardah

Feel the intensity"

Verbal text: No Transfer

\section{B. Beauty Icon on Nutri Shin's Hair Section}


The icon of beauty in hair, in pictures 1 and 2, hair as an icon of beauty. Wardah products reflect halal products. However, its use is not only focused on Muslim women. This is indicated by the wearing of headscarves and non-veiled costumes on advertising models.

\section{Upi in the Picture a) above Is the Icon of Hair Beauty.}

The screenshot of this TV commercial shows both verbal and nonverbal text. The verbal text is the expression, Upi, "Stop, don't use slowmo-slowmo anymore! Meanwhile, in nonverbal texts, it appears in the picture of a young woman as a canteen server, she is not veiled, is dressed in white, and has a slowmo appearance on her hair.

The two figures are Upi as the canteen server, and Mrs. Hesti is the canteen manager. Upi the canteen waitress is characterized as a slowmo-slowmo character, in the verbal text. Bu Hesti stopped Upi from continuing her action. She said "Upi, Udah stop, ga usah pakai slowmo-slowmo lagi!

The expression above is a form of persuasion sentence, prohibition. Even if it contradicts the principle of promotion in advertising, that statement makes canteen visitors curious. Why was Upi told to stop? The expression "Upi, Udah stop, ga usah pakai slowmo-slowmo lagi” is a structure of spoken language consisting of one sentence, but has two clauses, namely: 1) "Upi, udah aksimu stop!" (Upi, that is enough, stop your action), and 2) "kamu ga usah pakai slowmo-slowmo lagi!" (You don't have to move slowly anymore)

Thus, clauses (1) in common Indonesian expressions are as follows:

TABLE 1

COMMON INDONESIAN EXPRESSIONS (1)

\begin{tabular}{|l|l|}
\hline (1.a) & "Upi, sudah, berhentikan aksimu!"” \\
\hline (1.b) & "Upi, sudah, berhenti aksimu!"” \\
\hline (1.c) & "Upi, sudah berhenti!" \\
\hline (1.d) & "Upi, sudah!" \\
\hline
\end{tabular}

Meanwhile, the second clause (2) in official Indonesian is as follows:

TABLE 2

COMMON INDONESIAN EXPRESSIONS (2)

\begin{tabular}{|l|l|}
\hline$(2 . a)$ & "Kamu tidak usah melakukan gerak perlahan lagi!!" \\
\hline$(2 . b)$ & "Kamu tidak usah gerak perlahan lagi!" \\
\hline (2.c) & "Kamu tidak usah gerak perlahan!"” \\
\hline (2.d) & "Tidak usah gerak perlahan!" \\
\hline
\end{tabular}

When the two clauses are combined in official Indonesian, they become a command sentence, namely: "Upi, sudah tidak usah gerak perlahan!" Thus, the expression "Upi, Udah stop, ga usah pakai slowmo-slowmo lagi! is a slang language sentence structure in Indonesian. Meanwhile the official Indonesian structure is different: "Upi, sudah tidak usah gerak perlahan!"

In nonverbal texts, young women working as canteen waiters have lively movements. Upi does not wear a head scarf as a symbol of a devout Muslim woman, other than showing the glossiness of her hair that shines black, soft, and sways loosely when blown by the wind or any movement. The flexible softness of her hair is emphasized, whether it is left free or covered by a veil.

The clothes worn by the characters are white clothes. It looks like white was chosen as an intentional color. The meaning of white in general is the same as any other color which functions as a differentiator or characteristic of an object. However, white in this ad has various meanings. White as an object in this advertisement can be a symbol;

a) White as a symbol of simplicity: canteen waitresses do not look luxurious from the clothes they wear because white T-shirt is easier to see and can be accepted by everyone. Likewise, this simplicity appears in the use of the shampoo, easy to obtain and simple in appearance, b) White means holy and/or clean. As a symbol of purity and cleanliness, the canteen servers are more agile because they are free dandruff. The cleanliness is more radiant and the hair is shiny, soft and graceful because of using the Nutrishine shampoo. Thus the canteen waitress looks different from the others. c) White as a symbol of courage and innocence;, canteen servers have courage and confidence; Upi is confident because she has a better appearance than others. The shine of her hair and her hair fragrance made the canteen waitress dare to appear with slowmo-slowmo and high self-esteem.

Young women as characters in this advertisement do not veil, which indicates modern women. It is used as an index by using the words slowmo-slowmo. Thus, in the R-O relationship, Upi has objects occupying the icon, index, and symbol categories: as follows.

Icon The glossy black flowing hair that Upi shows in a slowmo-slowmo movement

\section{Nutrishine}

In the screenshot of the advertisement, the words "Wardah Shampoo Nutri Shin" are shown, followed by a text that reads: "Ms. Hesty..." "Hair looks healthy and shines, making you like a famous model. Always use the halal Wardah 
Nutrishine Shampoo with natural ingredients. It contains argan oil to nourish your hair to make it look healthy and shiny".

The nonverbal text depicts a young woman. She wears a light blue hijab. She also has a serious face. The end of the headscarf was blown away and the headscarf reads Wardah Nutrishine Shampoo, and at the end there is a pack of Nutrishine shampoo.

In the description above, the verbal text only says "Wardah Nutrishine Shampoo". The text only shows the shampoo brand. However, the text is followed by a speech which reads:

"Mrs. Hesty ...". The call from Upi, the canteen waitress to her boss, is a familiar greeting. Then, Mrs. Hesti looked back while walking. This is to show the slowmo-slowmo displayed by $\mathrm{Bu}$ Hesti. In such a display followed by a narrative by the advertiser in the form of an expression in a few sentences as below:

TABLE 3

NARRATIVE EXPRESSION IN INDONESIAN SENTENCES

\begin{tabular}{|l|l|}
\hline$(1)$ & Rambut tampak sehat bersinar. \\
\hline$(2)$ & Bikin kamu bagai model tenar. \\
\hline$(3)$ & Pakai selalu Wardah Nutrishine Shampoo yang halal dengan kandungan bahan natural. \\
\hline$(4)$ & Mengandung argan oil untuk nutrisi rambutmu agar tampak sehat dan berkilau". \\
\hline
\end{tabular}

The sentences mentioned in table above is a popular variety sentence which can be normally in Indonesia comment expression as follows.

TABLE 4

POPULAR VARIETY SENTENCE IN INDONESIAN VARIETY

\begin{tabular}{|l|l|}
\hline (1.a) & Rambut (Bu Hesti) tampak sehat bersinar (Ibu Hesti's hair is glossy) \\
\hline (2.a) & Tampilan rambut (Bu Hesti) seperti model tenar (her hair makes her look like a model) \\
\hline (3.a) & $\begin{array}{l}\text { Pakailah Wardah Nutrishine shampoo selalu. Shampoo ini halal dengan kandungan bahan } \\
\text { natural (Always use Nutrishine shampoo, it is halal with natural ingredients) }\end{array}$ \\
\hline (4.a) & $\begin{array}{l}\text { Wardah Nutrishine shampoo mengandung argan oil untuk menutrisi rambutmu agar } \\
\text { tampak sehat dan berkilau (Wardah Nutrishine shampoo contains argan oil to make your } \\
\text { hair healthy and glossy) }\end{array}$ \\
\hline
\end{tabular}

Thus, in sentence (1.a) "Rambut (Bu Hesti) tampak sehat bersinar" is a perfect sentence. Sentence on no. 1 does not have a straightforward subject matter like official Indonesian. Meanwhile in sentence 2) "Bikin kamu bagai model tenar" is a news sentence (declarative). The second sentence uses slang language, which is actually from the formation (2.a) "Tampilan rambut (Bu Hesti) seperti model tenar". Sentence 3) "Pakai selalu Wardah Nutrishine Shampoo yang halal dengan kandungan bahan natural" is a sentence of persuasion. The sentence has the form (3.a) "Pakailah Wardah Nutrishine Shampoo selalu. Shampoo ini halal dengan kandungan bahan natural!". Meanwhile, the fourth sentence is an imperfect sentence because it does not have a subject. 4) Mengandung argan oil untuk nutrisi rambutmu agar tampak sehat dan berkilau". This sentence can be corrected by adding a subject, namely (4.a) "Wardah Nutrishine shampoo mengandung argan oil untuk menutrisi rambutmu agar tampak sehat dan berkilau”.

Therefore, in the sentences above it can be stated that the sentence structure and the choice of words made by the advertiser are consonant with teenage slang language usage.

Meanwhile, the nonverbal text section shows the picture of a young woman wearing a light blue headscarf. She appeared with a serious face and stepped back after the dialogue. In her steps, Mrs. Hesti also did slowmo-slowmo. The end of the hijab blows in the wind and at the end is the Nutrishine Shampoo packaging. Thus, the iconic relationship to Nutrishine

Icon Image of a young woman in a veil blowing in the wind indicates bright, glossy hair; even when covered with a head scarf, her hair feels healthy, fresh and glossy.

\section{Iconicity on the Face / Facial Skin}

With respect to the facial skin, there is iconicity, in that beauty is marked iconically by the condition of the facial skin. There is the sense that a beautiful person is always marked by refinement, cleanliness, and joy shown on the face.

\section{Oil Control}

The beauty icon of the face / facial skin can be seen in the data for young women who are veiled and those who are not veiled. This is reflected in the advertisements, so the researchers used screenshots of women who are veiled and not veiled. In the screenshot, there is the text: "OIL CONTROL" followed by spoken language "with a matte finish + oil control".

Nonverbal text: the image of a young woman holding a paper, with a bright and smiling face, depicting after using light blue BB cream paper as the oil control tool is opened.

In the verbal text, there is "Oil Control" followed by the speech text: "with a matte finish + oil control". The phrases and expressions in this advertisement use a mixture of English and Indonesian. 
TABLE 5

A MiXTURE EXPRESSION IN INDONESIAN-ENGLISH PHRASE

\begin{tabular}{|l|l|}
\hline$(1)$ & $\begin{array}{l}\text { "Oil Control" in written form is in the form of a phrase, namely (a tool to control skin oil) a tool used } \\
\text { to determine whether a person's face is oily or not. Because there are various types of faces, some are } \\
\text { oily and some have dry skin. }\end{array}$ \\
\hline "Dengan hasil yang matte + oil control, hight by kilap" (With a matte finish, controlling oil, and \\
avoiding make-up that contains oil so that the skin doesn't get more shiny)
\end{tabular}

Even though the final result is matte, this make up product will not make your skin look dry, because this product is claimed to contain active minerals that can keep skin moist even when in an air-conditioned room. This product also protects the skin from being exposed to direct sunlight.

The use of make-up is different for each person, depending on their skin type. The messaging is that, especially for those of you who have oily skin types, you should avoid make up that contains ingredients such as mineral oil or petroleum jelly so that your skin doesn't get shiny. These ingredients can even cause a dull face and spots/ acne breakouts. So, to avoid this, use Wardah make-up products. This product is perfect for oily faces.

In nonverbal texts, a young woman with a bright face is holding a blue paper as a test for oil on the face. The paper functions as an "Oil Control". The woman is smiling, describing the result of using BB cream. Thus, the R-O oil control relationship has the objects occupying its icon, index, and symbol components, as follows:

Icon The use of $B B$ cream results in a bright, matte and non-oily facial

skin, as evidenced by the facial oil tester shown in the picture.

\section{Feel the Brighter You}

TABLE 6

Kind Of TeXt, Nonverbal And Verbal TeXt Of THE TEXT

\begin{tabular}{|c|c|}
\hline Text & Feel The Brighter You! Followed by spoken language: "Feel the brighter you" \\
\hline Nonverbal Text & $\begin{array}{l}\text { A9.1 Image of two young women } \\
\text { A9.2 A young woman with a headscarf, light blue dress, bright smiling face, and } \\
\text { pure white face. } \\
\text { A9.3 Young women not veiled, dressed in light blue, loose hair, clean white } \\
\text { faces, cheerful laughter. }\end{array}$ \\
\hline $\begin{array}{l}\text { The Verbal Text of The } \\
\text { Text }\end{array}$ & $\begin{array}{l}\text { "Feel The Brighter You!" (Feel the joy and brightness of your face), followed by } \\
\text { the phrase: } \\
\text { "Feel The Brighter You". (Feel the joy and brightness of your face). }\end{array}$ \\
\hline
\end{tabular}

In verbal texts, both spoken and written language, there is a repetition of concepts. In Indonesian, a repetition is used to emphasize something / key information to be conveyed. The text is in full English. This expression is used to convince speech partners or customers to want to use the $B B$ cream products offered.

Feel The Brighter You can hide acne scars, also known as dark spots. These scars arise due to the habit of squeezing or peeling pimples. Dark spots (blemishes) caused by acne scars are very disturbing for young women. The advertisement implies that this make up is able to disguise the acne scars.

In the nonverbal text, it shows two cheerful young women with different costumes, one wearing a head scarf, one not. The young woman wearing a headscarf has a light blue dress, bright smiling face, and pure white face. Meanwhile, the model who was not veiled, is dressed in light blue, has loose hair, and a white face. Both were clean and laughed cheerfully.

Thus, the R-O relationship, Feel The Bright You has the objects occupying its icon, index and symbol categories as follows:

Icon Feel the joy of confidence about your face after using the $B B$ cream treatment.

\section{Wardah Advertisement Iconicity about the Eyes}

The first example on the iconicity of Wardah's cosmetic advertisements on eye make-up in relation with mascara might be found in the following table:

TABLE 7

WARDAH'S COSMETIC ADVERTISEMENTS ON EYE MAKE-UP (1)

\begin{tabular}{|l|l|}
\hline Text & "EXTRA VOLUMIZING" \\
\hline Narration followed & $\begin{array}{l}\text { Ekstra tebal, ekstra lebih". The verbal text shows that 1) "Extra Volumizing" } \\
\text { (extra) followed by speech, and 2). "Ekstra tebal, Ekstra lebih". (Extra thick and } \\
\text { more extra) This means that with the use of extra volumizing the eyelashes can } \\
\text { be thicker and darker. }\end{array}$ \\
\hline
\end{tabular}

In verbal text number 1 is English. Meanwhile the spoken language (number 2) is the Indonesian language translation of number 1 . The use of writing and expressions is in the form of phrases, with written verbal texts using English, 
meanwhile the spoken language expressions use Indonesian The text is written "Extra Volumizing" in English, meaning extra thick eyelashes.

The use of nonverbal text shows how to use mascara correctly, so that the eyes look perfect. The image background uses a dark blue color and highlights the contrast with the black mascara and eyelashes. In addition, the white color of the face also appears clearer. The color composition in the image shows blacker, thicker eyelashes. Thus, the R-O, Extra Volumizing relationship has objects occupying its icon, index, and symbol components as follows.

Icon The use of Extra Volumizing mascara makes eyelashes look blacker and thicker.

\section{E. Hi-Black Liner}

With respect to the iconicity of Wardah's cosmetic advertisements on eye make-up, the second example used for analysis is an advertisement for eye-liner:

TABLE 8

WARDAH'S COSMETIC ADVERTISEMENTS ON EYE MAKE-UP (2)

\begin{tabular}{|l|l|}
\hline Verbal Text & $\begin{array}{l}\text { "Wardah Eye expert Optimum Hi-Black Liner". Followed by the spoken } \\
\text { language text: "Wardah Feel the intensity" }\end{array}$ \\
\hline Nonverbal Text & 1. The face of a young woman is shown in full \\
& 2. Bright gaze \\
& 3. Clear eyes \\
& 4. Eye light intact \\
5. Optimum Hi-Black Liner
\end{tabular}

The use of verbal text in the form of writing,

(1) "Wardah Eye Expert Optimum Hi-Black Liner" (the name of a product from Wardah cosmetics), followed by speech

(2) "Wardah Feel the intensity" (Wardah has intensity)

Both written and spoken texts use a mixture of language between Indonesian and English or just English. This kind of vocabulary is the language of "millennial" teenage girls.

Meanwhile, in the nonverbal text the appearance of a beautiful, elegant young woman's face is show against the background of the inscription "Wardah Eye Expert Optimum Hi-Black Liner". Besides that, the color combination is very harmonious between the clothes, the face and the background. This is considered a perfect beauty.

Thus, the R-O, Hi-Black Liner relationship has the Objects occupying its icon, index, and symbol components as follows:

Icon The young woman wearing the Optimum Hi-Black Liner looks beautiful and perfect

\section{F. The Iconicity of Lips as Female Beauty}

1) Brave Lipstick

TABLE 9

THE ICONICITY OF LIPS As FEMALE BEAUTY

\begin{tabular}{|l|l|}
\hline Text & Red-dicted Brave \\
\hline Verbal Narrative & "Merah, untuk percaya diri" \\
\hline Nonverbal Text & E4.1 Image of a young woman \\
& E4.2 Not veiled \\
& E4.3 Wearing red lipstick \\
\hline
\end{tabular}

In the verbal text there is writing: 1) "Red-dicted Brave" (this equates the red "red-dicted" lipstick line with bravery) followed by speech, and 2) "Merah, untuk percaya diri" (red, for confidence)

This expression is a translation of the concept from English into Indonesian. .This repetition of the concept using text with a similar meaning in different languages serves to emphasize the meaning or message of the text, which is "wear red, to be confident". This expression is an advertising language directed at young women in the hope that they will want to feel confident and immediately buy and use Wardah products.

In the nonverbal text, a young woman is shown wearing red lipstick, to be "confident". The young woman feels brave after wearing red lipstick. In addition, the confidence in young women is more visible because when they wear lipstick correctly their lips can appear to be more perfect in shape. For young women, the perfect color and shape of the lips is a symbol of beauty for their people. Thus, the R-O, Lipstick Brave relationship has the objects occupying its icon, index and symbol components as follows:

Icon $\quad$ Young women feel confident when they wear red lipstick 
2) No Transfer

TABLE 10

VERBAL AND NONVERBAL TEXT OF "NO TRANSFER"

\begin{tabular}{|l|l|}
\hline Verbal text & No Transfer \\
\hline Nonverbal Text & P3.1 Picture of a young woman's lower face \\
& P3.2 Eating a sponge cake \\
& P3.3 She has already put on lipstick \\
& P3.4 The lipstick does not smudge or transfer onto the cake \\
\hline
\end{tabular}

Verbal use is only written text "No Transfer" (does not fade). The message that the new Lip Cream formula [P], not fade is written in English. The use of English is dominant in the advertising language. Thus it can be concluded that the target of advertising is young women so that the use of the language is English.

The nonverbal text in the image is a visual proof that, even when eating a sponge cake, this lipstick still does not fade. The color of the lipstick on the lips does not diminish and does not fade. In the picture, a young woman demonstrates that her lipstick doesn't fade when she eats a sponge cake. Thus, the R-O, No Transfer relationship has the objects occupying its icon, index, and symbol components as seen as follows;

Icon This lipstick does not fade on young women even when eating cake.

\section{CONCLUSION}

This paper sets out to interpret Wardah's advertisements by identifying the signs contained in the text (both verbal and nonverbal). This research is significant for the study of the concept of beauty "Beauty from the Heart" in Wardah's cosmetic advertisements. The concepts of being beautiful from inside and beauty from the outside are two distinct concepts of beauty that Wardah's cosmetic advertisements attempt to put together - implying that both arise as the result of the use of cosmetic tools. Beauty from the inside is inner beauty manifested in attitudes and behavior, while beauty that results from using cosmetics is purely physical beauty. Furthermore, examining the relationship between representaments and iconic objects in Wardah's cosmetic commercial television advertisements for shampoo, BB cream, mascara, lipstick, and the social activities portrayed, this study found that there are several RO relationships including icons, indexes and symbols: 1) The beauty icons in Wardah's cosmetic advertisements are found in the hair, the face, the eyes and the lips; 2) Index signs in Wardah's cosmetic advertisements include the hair care behavior index, the facial skin care index, the eyelash care index, a lifestyle index of upper and lower strata of society, and a health index; and 3) Symbols in Wardah's cosmetic advertisements are comprised of (1) beauty symbology, (2) religious symbology, (3) corporate symbology, and (4) social symbology.

\section{REFERENCES}

[1] Abidin, S. (2018). “Analisa Semiologi Pesan Moral pada Film "Beauty and The Beast Live Action" Jurnal Komunikasi dan Media Vol. 2 No2 Februari 2018 ISSN. 2527-8673, E-ISSN. 2615-6725.

[2] Aminuddin. (2000). Semantik: Pengantar Studi Tentang Makna, Arthur Asa Berger, Tanda-Tanda dalam Kebudayaan Kontemporer. Tiara Wacana: Yogya.

[3] Art, V. Z. (1991). Fiksi dan Non Fiksi dalam Kajian Semiotik. Jakarta: Intermasa.

[4] Art, V. Z. \& Panuti, S. (1992). Serba-Serbi Semiotika. Jakarta: Gramedia.

[5] Budiman, K. (2011). Semiotika Visual: Konsep, Isu, dan Problem Ikonitas. Yogyakarta: Jalasutra.

[6] Dewi, M. C. (2013). "Representasi Pakaian Muslimah dalam Iklan (Analisis Semiotika Charles Sanders Peirce pada Iklan Kosmetik Wardah di Tabloid Nova)" Jurnal Komunikasi PROFETIK.Vol. 06, No. 2, Oktober 2013. p. 61-83

[7] Djamereng, A. (2018). "Analisis Semiotika pada Iklan Televisi (Iklan Wardah dan Iklan Total Almeera)". Jurusan Komunikasi dan Penyiaran Islam, Al-Khitabah, Vol. IV No. 1 April 2018: 1-16.

[8] Hasyim, M. (2015). Myth And Ideology Construction In Indonesia Television Advertising: A Semiotic Based Approach. Jurnal: International Journal of Communicationand Media Studies (IJCMS) ISSN (P), 5(1).

[9] Hoopes, J. (Ed.). (2014). Peirce on signs: Writings on semiotic by Charles Sanders Peirce. UNC Press Books.

[10] Machmud, M., Hasyim, M., \& Rahman, F. (2021). Representation of Halal Tourism: How do tourists find information about really halal food. LINGUISTICA ANTVERPIENSIA, Issue 3 Vol. 2021. 6730-6739.

[11] Nugroho, A. C. "Komunikasi Tanda dan Makna dalam Pandangan Cs Pierce Dan Saussure" Majalah Ilmiah Semi Populer Komunikasi Massa Vol. 14 No. 2 (Juli - Desember 2018) Hal: 169 - 178. Balai Pengembangan SDM dan Penelitian (BPSDMP) Kominfo Jakarta Badan litbang SDM.

[12] Osianita, Y., Eko, A. B., \& Oemar. (2015). “Kajian Semiotika Iklan Produk Kosmetik Mustika Ratu Tren Warna.” Jurnal Pendidikan Seni Rupa. Volume 03 Nomor 02 Tahun 2015, 188-195.

[13] Rahmaniah, A. (2012) Budaya dan Identitas. Dwiputra Pustaka Jaya, Sidoarjo

[14] Rahman, F. (2017). Cyber literature: A Reader - Writer interactivity. International Journal of Social Sciences \& Educational Studies, 3(4), 156-164.

[15] Rahman, F., \& Weda, S. (2019). Linguistic deviation and the rhetoric figures in Shakespeare's selected plays. XLinguage" European Scientific Language Journal", 12(1), 37-52. 
[16] Sari, G. G. (2014). "Analisis Tanda Verbal Iklan Smartphone Ntt Docomo Di Media Televisi Jepang: Kajian Semiotik" JAPANOLOGY, VOL. 2, NO. 1, Februari 2014: 67 - 77.

[17] Situmeang, \& Ilona, O. (2015). "Representasi Wanita pada Iklan Televisi Wardah Kosmetik (Analisis Semiotika Roland Barthes Wardah Inspiring Beauty Versi True Colours)". Jurnal Semiotika Volume 9 Nomor 1 Juni 2015, 113-141.

[18] Sobur, A. (2004). Semiotika Komunikasi. Bandung. Rosda.

[19] Suherdiana, D. (2008). "Konsep Dasar Semiotik dalam Komunikasi Massa menurut Charles Sanders Pierce" Jurnal Ilmu Dakwah Vol.4 No. 12 Juli-Desember 2008, 371-407.

[20] Weda, S., Atmowardoyo, H., Rahman, F., \& Sakti, A. E. F. (2021). Linguistic aspects in intercultural communication (IC) practices at a higher education institution in Indonesia. Eroupean Language Scientific Journal, 14, 2-6.

[21] Wibowo, E. (2013). “Makna Semiotik dalam Novel Anomie Karya Rilda A. Oe. Taneko. Kantor Bahasa Lampung.

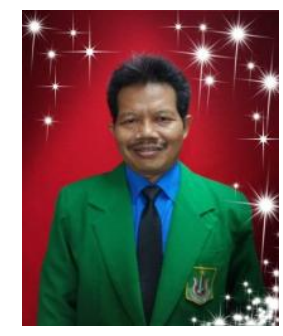

Somadi is a postgraduate student of Hasanuddin University majoring in linguistics. He has worked as a senior lecturer at the National University, Jakarta Indonesia.

Tadjuddin Maknun is a senior lecturer at Hasanuddin University. He teaches in the Faculty of Cultural Sciences.

Ikhwan M. Said is a senior lecturer at Hasanuddin University. He teaches in the Faculty of Cultural Sciences.

Munira Hasjim is a senior lecturer at Hasanuddin University. She teaches in the Faculty of Cultural Sciences. 